\title{
TRENT RIVER SYSTEM AND SAINT LAWRENCE OUTLET
}

BY ALFRED W. G. WILSON

(Read before the Society January 1, 1904)

\section{CONTENTS}

Page

moduction . . .

Geology of the area under discussion $\ldots \ldots \ldots \ldots \ldots \ldots \ldots \ldots \ldots \ldots \ldots \ldots \ldots \ldots 2$

The bedrock geology ................ . . . . . . . . . . . 212

Pleistocene and recent geology ........................ 213

Topographic features of the country east and northeast of lake Ontario . . .. 215

General description of the topography................... 215

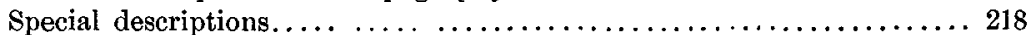

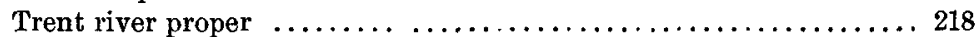

Prince Edward County topography ................... 219

Other rivers in the province of Ontario................. 220

Rivers in New York state . . . . . . . . . . . . . . . . . . . . 221

Origin of the bedrock topography $\ldots \ldots \ldots \ldots \ldots \ldots \ldots \ldots \ldots \ldots \ldots \ldots \ldots$

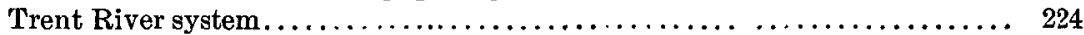

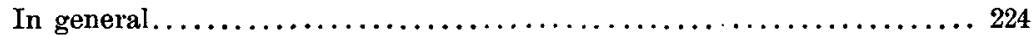

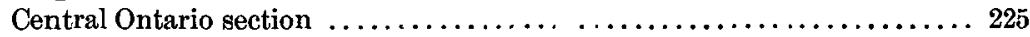

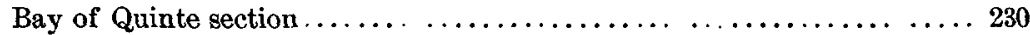

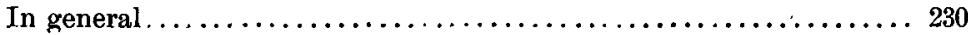

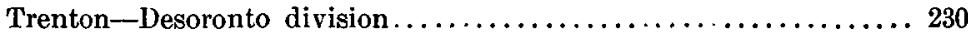

Long reach and Napanee river . . . . . . . . . . . . . . . . 231

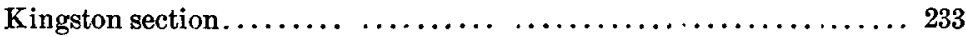

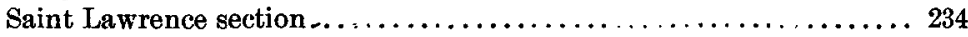

Fault theory of origin of Bay of Quinte depression............. 234

Notes on other streams tributary to lake Ontario from the east .........236

The Saint Lawrence outlet............................ 238

Summary and conclusions............................. 240

\section{INTRODUCTION}

The present paper is offered as a contribution to the already voluminous literature on the origin of the basins of the Great lakes in the belief that the matter here presented not only is of great importance in the attempt to find a correct solution of the problem, but also because, so far as the writer's study of the literature has gone, the facts here set forth have been largely overlooked in the earlier studies of this question. In 
a paper published three years ago the writer very briefly outlined some of the facts and conclusions given here in more detail.* The important bearing which the studies then made appeared to have on the origin of the Saint Lawrence outlet from lake Ontario led him to delay fuller publication until he had been able to continue and extend the field work begun at that time. During the past two summers every locality mentioned in the context has been visited, and in many cases the writer has been able to revisit (in a few instances several times) critical points after the first draft of this paper was prepared. The absence of good maps of any kind for the province of Ontario, except some old county maps of the eastern portion of the province, has greatly hampered the work and necessitated longer and more detailed work in the field than would otherwise have been necessary.

The published sheets of the topographic map of the adjacent parts of New York state have proved of great assistance. As might be expected, the topography on the Canadian side of the Saint Lawrence is very similar to that across the boundary. One of the maps, which accompanies this paper (plate 8), prepared from the New York topographic map of a portion of this area, will thus serve to illustrate the type of bed-rock topography that is characteristic of the whole region under discussion.

The writer is indebted to Dr F. J. H. Merrill, State Geologist of New York, for copies of the Saint Lawrence sheet of the geologic map of New York state, and to Lieutenant Colonel Anderson, Chief Engineer, Department of Marine and Fisheries, Ottawa, for very detailed profiles from which the sections across the bay of Quinte were prepared. Above water-level the sections were surveyed by the writer. The other maps which accompany this paper were prepared from the admiralty charts of the bay of Quinte, the charts of lake Ontario and the Saint Lawrence river, published by the War Department, Washington, and from county maps.

The discussion deals with the topographic features of that portion of the province of Ontario which lies east of lake Simcoe and north of lake Ontario, together with that portion of New York state which borders on the eastern end of lake Ontario. The eastern limit of the area is the Thousand Island group.

\section{Grology of the Area under Discussion}

THE BEDROCK GEOLOGY

As is well known, Saint Lawrence river, in the vicinity of the Thousand

*A. W. G. Wilson: Physical Geology of Central Ontario. Trans. Can. Inst., vol. vii, 1900-'01, p. 168 et seq. 
islands, crosses the Frontenac axis, a narrow neck of Archean rocks which connects the Adirondack region with the greater Archean areas of Canada. The Archean rocks, of which the Frontenac axis forms a part, underlie the eastern, northeastern, and northern part of the area under discussion. West and south of the Archean areas the region is underlain by rocks of Ordovician age, chiefly Black River or Trenton limestones. Outcropping from beneath the Black river, and also occurring in several cases as outliers on the Archean areas, are a few feet of sandstones, some of which are classed as Potsdam. It is not impossible, in Ontario at least, where they are very much less well developed than in New York state, and are usually of a somewhat different texture, that they may be contemporaneous with the lower part of the Black River formation. In the present discussion these sandstones are only of relatively minor importance. The dominant topographic features of the region are controlled either by the limestone or by the Archean rocks.

\section{PLEISTOCENE AND RECENT GEOLOGY}

In this locality, from the close of the Trenton until the Pleistocene, time is not represented by any deposits. Any that ever existed have long since been eroded away. The Pleistocene deposits are represented by typical boulder clay and by deposits of stratified sands and gravels. The distribution of these materials differs greatly in the different parts. Throughout the Archean portions of the region the deposits are confined largely to the depressions, with but very few scattered boulders or patches of till or sand and gravel on the sides or summits of the Archean ridges. In very few places does the amount of material deposited obscure the bedrock topography of the Archean terranes, the thickness rarely exceeding a few feet. The deposits are an important factor in the modification of the topography of the Archean regions as to relatively unimportant detail but not as to general features.

On the other hand, in the parts of the region underlain by Ordovician rocks the conditions are in places somewhat different. In the central parts of the district, on either side of the Saint Lawrence, the Pleistocene deposits form only a thin veneer, except very locally in a few cases. There are many large areas where almost bare rock is exposed for several square miles at a time. In very few cases does the soil cover exceed 2 feet, except in the bottoms of some of the valleys, and very frequently not even there. As the measure of relief in the district under discussion often exceeds 150 feet, and thus in comparison with the thickness of the Pleistocene deposits is very great, it is possible to determine without the slightest doubt the nature and character of the bed-rock topography of 
those regions. In New York state, south of Stony creek (about 6 miles south of Sacketts harbor), the bedrock topography becomes obscured by morainic deposits. But even here, particularly in the vicinity of the lake shore, certain of the features whose presence would be expected from their occurrence farther north are found to be present, partly obscured by drift it is true.

In Ontario the area whose bed-rock topographic features can be accurately determined includes the whole of Prince Edward county. Here, although there is abundance of drift as a thin veneer, the farmer in plowing is often turning over more or less decayed rock, unquestionably in situ, which the writer regards as probably of pre-Glacial origin, a question to which reference will be made below. The heavy morainic deposits of central Ontario lie close to the lake from near Toronto to the vicinity of Trenton. At Trenton their southern edge turns inland, and they extend eastward to near the village of Croydon. Northward they reach almost to the edge of the Black River limestones at the borders of the Archean; but they are not continuous, numerous exposures of bed rock being known north and east of Trenton. South and east of the line between Croydon and Trenton the character of the bed-rock topography can be determined without difficulty. All along the line of contact between the Black River limestones and the Archean, within the limits of the area under discussion, from the south of Carthage, in New York state, to west of lake Simcoe, in Ontario, the topographic features of the limestones are practically unobscured by drift. Outcrops without cover of any kind are very frequent, particularly in the province of Ontario, where there seems to be much less drift cover than over the similar region in New York.

Glacial or post-Glacial movements have produced one very important change. The present attitude of the region is not that which it had at the time the topographic features it now possesses were produced. There has been local differential movement which has modified the original relative attitudes of the different parts of the region. Probably there was at the same time a considerable amount of regional movement by which the general attitude (with respect to sealevel) of the whole area was altered to its present position, accompanied by certain modifications of the drainage lines. Recent process has effected only minor and local changes, such as the partial erosion of portions of the drift deposits or the local modification of the topography where differential movements or other causes had produced lake basins. One of the most noticeable of these recent changes is the blocking of the lower reaches of a number of partly submerged valleys by the formation of bars across their ends, 



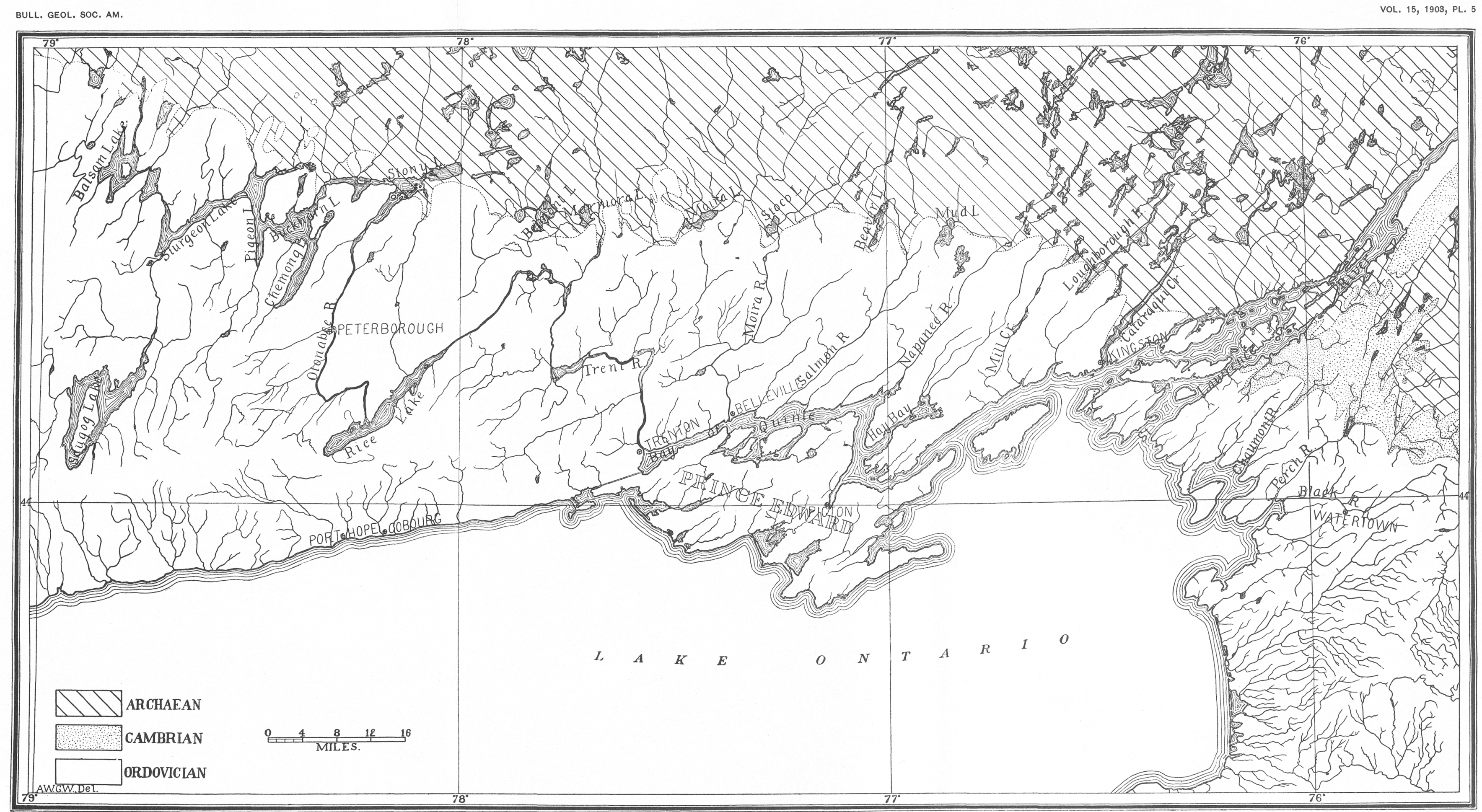

GEOLOGY AND DRAINAGE FEATURES OF THE COUNTRY NORTH AND EAST OF LAKE ONTARIO 
thus producing a series of small lakes bordering the eastern end of lake Ontario.

Topographic features of the Country East and Northeast of LAKE ONTARIO

GENERAL DESCRIPTION OF THE TOPOGRAPHY

The topography of the portion of the area underlain by Archean rocks is that of one of the partly dissected pre-Ordovician facets of the Laurentian peneplain.* In this particular locality it is characterized by the occurrence of longitudinal, often steep-sided, more or less rounded or domed ridges, with deep valleys between, characteristic of the Archean areas where they are bordered by the Paleozoics. The maximum relief rarely. exceeds 150 feet. The lower portions of the depressions often form lake basins, and the longitudinal valleys are usually the basins of streams. A reference to the accompanying areal map (plate 5) will show the general longitudinal distribution of the water bodies, which, in the absence of contour topographic maps, will serve as a valuable index to the nature of the topography.

In detail it is found that between the major longitudinal valleys of the Archean areas the general surface of the tops of the intervalley ridges (where these are not too narrow) is mammillated or undulating. Everywhere the tops and often the sides of the ridges have been smothered and scoured, and all now present a surface of relatively fresh rock. As has been pointed out elsewhere, $\uparrow$ the main topographic features, including this last characteristic, are probably in all their essential features of pre-Ordovician date.

The Ordovician limestones lie with a very gentle dip away from the Archean areas. North of the east end of lake Ontario the dip is approximately southwest. East of lake Ontario it is more westerly. Especially near the Archean regions there are local undulations and other irregularities caused by the unevenness of the floor on which the sediments were laid down. Subsequent to their deposition and before the present drainage lines were developed, erosive processes planed off the region, producing a nearly even surface, truncating the beds at a slight angle both with the dip and with the line of strike, leaving the imbricating edges of the different beds pointing toward the old land. That surface has now become somewhat warped, the lowest part being in the vicinity of the valley of the Saint Lawrence river. The general slope of

\footnotetext{
*A. W. G. Wilson: The Laurentian Peneplain. Chicago Journal of Geology, vol. xi, 1903, p. 615 et seq.

f Chicago Journal of Geology, loc. cit., p. 656 .
} 
the upland or intervalley areas north of lake Ontario is to the south, or toward the lake. All the present valleys north of lake Ontario, which have been cut in the limestone, slope toward the southwest-not, however, always in accordance with the dip, though they are in accordant positions with each other. Hence the grade of the valley bottoms is much less than the slope lakeward from the Archean areas, the length of the valleys being thus proportionally longer than the line of maximum slope from their heads near the Archean to the nearest part of the lake into which flow the streams occupying the bottoms of the valleys. The direction of flow of the present streams is not that which they would normally assume in consequence of the slope of the general surface of the country.

In New York, on the other hand, the dip of the slope-plane of the bottoms of the valleys is in nearly the same direction as that of the plane of the dip, and that of the plane of the upland surface, but the three different planes are at slightly different angles to the horizon, that of the dip being greatest, and that of the valley bottoms least. In Ontario the direction of slope of the valleys is in a direction accordant with the similar valleys developed to the south of the Saint Lawrence in New York. In Ontario these differences in direction of slope between the general surface, the plane of the valley bottoms, and the plane of the dip are so well marked in places that in the field the discordances can readily be rognized by the eye alone.

Subsequent to their planation the limestone areas must have been uplifted and partly dissected, as in their present attitude we find that they present a well marked cuesta front toward the old land, and are dissected by a well developed system of valleys to whose existence reference has already been made. The valleys and the lowland in front of the cuesta are regarded as of later date than the plane which bevels off the upland surface, since there is everywhere a well marked discordance between the gradient curves of the valley sides or cuesta front and the very much flatter surface curves of the even uplands.

The cuesta front as it now appears is often a steep, inaccessible cliff. The height varies up to a maximum of about 150 feet. The crest of the cuesta is usually formed by heavy-bedded Black River limestones. At its base there are often found softer calcareo-arenaceous, at times argillaceous, beds. These latter, or else sandstones of Potsdam age, often underlie the narrow belt of lowland which lies in front of the cuesta, between it and the oldland. In Ontario the lowland in front of the cuesta is also frequently located on Archean rocks. These lowland areas often form basins, in which are located small, shallow lakes.

The valleys which lie on the limestones are of two types-those which 
discharge waters from the inner lowland into the Ontario lowland, and thus traverse the limestone belt, and those whose catchment basins are located wholly on the linestone uplands.

In general it is found that the upper parts of the valleys of the first type are very steep-sided and flat-bottomed where they traverse the cuesta. In many cases both sides are inaccessible, though not necessarily vertical, cliffs as much as 125 feet in height, with a flat-bottomed valley between. The width of the valley varies somewhat, but rarely exceeds a mile and a half or is less than half a mile. In most cases the upper parts of these valleys, near where they pass through the cuesta front, form the basins of long, narrow lakes. Such lakes as those on the Cataraqui creek above Kingston mills, Collins lake, Loughborough lake, Sydenham lake, and several others in Ontario are of this type. The water seems in some cases to be held back by a drift dam, which partly blocks the lower part of the valley. Certainly in some cases, in all probability in most cases, the present lake basin is a rock basin and the existence of the present lake is due either to warping or possibly to differential erosion by ice.

These valleys in their lower reaches toward the lake become broader. In New York the sides usually bave about equal slopes, the general trend of the valley being in the same direction as the dip of the rocks. North of lake Ontario, however, where the trend is not always accordant with the dip, in many instances the southeast side of the lower portion of a valley is much steeper than the northwest side. Many of the valleys are bounded by a well marked rock escapement, which may be traced from the cuesta front along the valley side almost to lake Ontario. In their lower reaches the breadth of this first type of valley may be as much as 5 miles. The intervalley uplands in ground plan will thus have the form of a scalene triangle, with the base at the cuesta front and the apex of the triangle pointing toward lake Ontario. The inland portions nearest the cuesta are broad and flat, with very little or no soil cover. As the valley widens the gradual encroachment of adjacent sides of neighboring valleys narrows the flat intervalley area. In places, however, it so well retains its character that it ends in a wedge point which can be located in the field without difficulty, where the encroaching gradient curves of adjacent valley sides have met. In a few places close to the discharge point of the present valleys on the bay of Quinte the present surface of the intervalley ridge will thus lie below the plane of the upland surface. The majority of these valleys can be traced by aid of the soundings for some distance out from the shoreline and under the waters of the present lake Ontario.

The valleys of the second type, which head on the upland, are, in their 
upper reaches, mere flat shallow depressions on the limestones. As we descend any one of them we find that it gradually deepens; usually its southeast side soon becomes marked by a low cuesta-like escarpment, with a steep slope toward the valley and a gentle slope away from the crest. The northwest side is less steep than the other, but is steeper than the normal outer slope of the minor cuesta which forms the southeast side of the next adjacent valley northwestward. The valley has been formed by an incision of the rocks, and the difference in slope of the two sides is due to the relation existing between the direction of the valley and the dip of the rocks. These valleys slope, as do those of the first type, in a direction a little to the south of the strike of the rocks, but not in the direction of the dip. There are some special cases which will be referred to in the more detailed discussion of the Trent River system in a subsequent section.

It very frequently happens that valleys of the first type are continuous with longitudinal valleys developed on the Archean areas, and the headvalley lake often occupies a basin part of which is underlain by Archean rocks. The depth of the upper part of these valleys is in part controlled by the relatively harder Archean rock, the latter often being exposed in the bottom of a valley some miles away from the cuesta front, while the valley walls are of limestone.

\section{SPECIAL DESCRIPTIONS}

Trent river proper.-The most important stream in the region is the Trent river. What is usually considered as the main stream of the river system heads in a small lake in the Laurentian region of central Haliburton county. This stream, known as the Gull river, flows southwest in a valley bounded by Archean rocks to Mud Turtle lake, a partly flooded valley of the first type, noted above. Between here and Balsam lake the stream continues in this valley. Balsam lake is a broad shallow depression, located on the Black River cuesta, in which the river expands. Between Balsam lake and lake Ontario the stream follows a very remarkable zig-zag course, alternately occupying an old more or less drift-blocked rock-bound valley, usually of the first type here described, and flowing in a new channel across one of the intervalley areas. In these old valleys it usually expands to form lakes. Following down stream from Balsam lake, these lakes are named respectively Cameron, Sturgeon, Pigeon, Buckhorn, Love Sick, Deer, Stony, Clear, Katchewanaka, and Rice. Scugog lake and Chemong lake also belong to the system, though they are not on the direct line of the main stream. Between these various lakes, excepting the last two, Katchewanaka and Rice, the stretches of running water are very short and are not usually 
given any specific name. Between Katchewanaka and Rice lakes the main stream is called the Otonabee river. Below Rice lake to Trenton it is called the Trent river. From Trenton to lake Ontario it is usually called the bay of Quinte. It is thus found that the Trent is really a very complex system of valleys; and a more detailed description and discussion is given in the special paragraphs on the Trent River system.

The following table gives the elevation above sealevel of each of the more important lakes of the Trent River system :

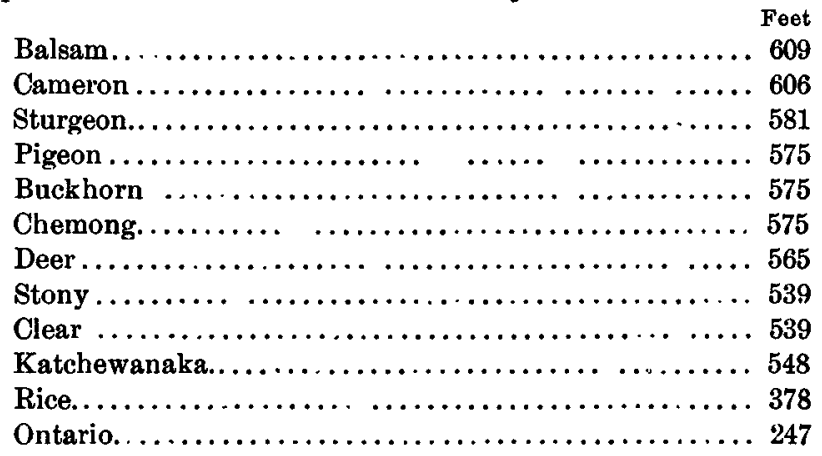

Prince Edward County topography.-Two of the principal valleys, whose union forms the bay of Quinte as it now is, have had a notable effect on the development of the topography of that part of the district known as Prince Edward county. The two parts of the bay, known respectively as the Long reach (or the Ninemile reach) and the Twelvemile reach, converge southwestward toward Picton bay. Southwest from Picton toward East lake they continue as a single well marked valley, partly drift blocked at Picton, with a steep, often cliffed, wall on the southeast side. The Long reach has intercepted any drainage which normally would have crossed Prince Edward from the northeast, and so we find that its western wall is marked by a cliff whose present height above waterlevel is about 150 feet, or whose crest rises about 185 feet above the bottom of the now partly submerged valley. There are but two minor obsequent streams that have barely incised notches in the cliff front. On the upland, west of the Long reach, head several small streams whose valleys belong to the second type of valley mentioned above. In crossing Prince Edward county toward the southeast, ten well marked low cuestas, including the one between East lake and Picton bay, with north facing steep fronts and gentle south dipping back slopes, are met with, besides a few of minor importance. It has not yet been possible to carry the detailed study of the topography far enough to determine the interrelations of all of these valleys whose existence is thus indicated, but 
the main features have been determined. The minor cuestas between Consecon lake and West lake, four in number, are the southeast sides of valleys of the second type which head on the upland adjacent to the Long reach. The cuestas north of Consecon lake are associated with the complex system of valleys, parts of which form the present bay of Quinte, between Trenton and the Long reach. Those south of East lake, except the one immediately adjacent to the lake, are also associated with valleys of the second type.

Other rivers in the province of Ontario.-Tributary to the bay of Quinte there are a number of other streams traversing valleys of the types here described. The largest of these is the Moira. Heading on the Archean, it runs southwest to the cuesta front at a point 5 miles west of the village of Madoc. The main stream now turns eastward along the lowland in front of the cuesta, expanding slightly at Moira lake, to Stoco lake, also in front of the cuesta. From here it passes into the cuesta through one of the valley openings of the first type and continues along the depressions for several miles. The lower portions of the valley are blocked by heavy accumulations of drift, and the river has taken a new channel, not directly associated with any of the old rock valleys, though it reaches to bed rock in several places. In the vicinity of Plainfield the Moira receives an important tributary from the northeast. This tributary heads in a direct line with Beaver lake, and occupies a valley which may be the lower course of an old valley of which Beaver lake marks the site of the upper narrow portion, the part between being driltblocked. There are also several tributary streams of minor importance heading on the limestone uplands and occupying rock valleys which have well defined sides near their junction with the main valley.

Omitting further reference to several minor streams, the next river of importance is the Salmon river. This heads in Beaver lake a little west of Tamworth and crosses the limestone area in a well defined straight valley, easily traceable by its high, well marked rock scarps the whole way across. The Napanee river, Big creek, Mill creek, Collins creek, and Cataraqui creek all cross the limestone regions in definite, straight rock-sided valleys of the first type. Between these streams, and also in some cases tributary to them, are several minor streams occupying valleys of the second type. In the case of Cataraqui creek, it is interesting to note that in cutting downward the stream which carved the valley encountered an Archean ridge buried in the limestone, through which it has carved a narrow canyon (at Kingston mills), the valley on the limestones above and below being much broader than here-a typical "shut in" of the Missouri type, in fact. 
Rivers in New York state.-The Bateau channel of the Saint Lawrence river below Kingston is a partly submerged portion of the eastern end of the Twelve Mile reach of the bay of Quinte. The American channel, as will be shown subsequently, is also one of those submerged valleys. Between cape Vincent and Sacketts harbor a number of southwest-flowing streams occupy well defined rock valleys. Of these Chaumont river, Perch creek, and the Black river cross the limestone areas in valleys of the first type. Mud creek, Muskalonge creek, and a few other minor streams occupy valleys of the second type. The most important of these streams is the Black river, which to the south of Carthage flows for a long distance in the position of a normal subsequent stream along the lowland between the limestone cuesta and the Adirondack oldland. South of Sacketts harbor there are a number of southwesterly flowing streams all of which head on the upland, and most of which show in parts at least that the valleys which they occupy, though more or less drift-blocked, are of the types here described. A more detailed reference to them is not necessary in the present discussion.

Enough has already been said to show that on either side of the present Saint Lawrence outlet we have a well marked system of southwest trending rock-walled valleys, with a number of similar rock-walled minor valleys tributary to them and joining them at accordant levels.

Before describing these valleys more in detail and before discussing their inter-relations and their relation to the Saint Lawrence outlet, it will be well to consider the question of their probable origin and its date.

\section{ORIGIN OF THE BEDROCK TOPOGRAPHY}

That these valleys are due to normal processes of stream erosion is attested by their form and shape and by the uniform accuracy of the adjustments between tributary and main valleys. North and east of Trenton and west as far as the headwaters of the Trent system, many of these valleys are found more or less occupied by drift deposits. The lowest of these deposits, as shown in the section cut by the Trent river north of 'Trenton and in numerous other sections along lake Ontario, is a clay till of what is probably the second glacial epoch. This till is overlain by other deposits of several interglacial and glacial epochs respectively. Beneath the till, which is rather widespread, the striated and grooved rock surface is frequently found. It is certain that many of the valleys-and thus by inference that all of them, since they are very closely alike in form and adjustment-antedate the ice-sheet which deposited the lowest till-sheet of central Ontario and produced the striated rock surface. 
The direction of movement of the ice-sheet which produced the striations on the uplands was to the west of southwest in Ontario. In New York and in the vicinity of the Thousand islands it is a little more southerly, the striæ running about south 65 degrees west, true. That this westerly direction, as shown by the striæ, is the general direction of the ice movement is also shown by the direction of the longer axes of the very numerous and large drumlins in Huntingdon township, North Hastings (county), and elsewhere. The direction of the general movement of the ice on the uplands was quite independent of the trend of the valleys. In some cases it has been parallel to them, in others across them or at various angles to their axial lines. In one locality, near the head of Mill creek, striæ are found crossing obliquely downward into the valley from the northeast. At this locality the valley sides are steep cliffs and at one point the ice in its descent into the valley appears to have broken away a short piece of the crest of the cliff, producing a remarkably smooth curved surface at the very edge. Near the same locality, in the bottom of the valley about midway between the walls, striæ are found parallel to the valley sides and thus oblique to the general direction of ice movement, showing that here at least there was a local differential movement of the ice sheet, assuming that these striæ, which are but a few hundred yards apart, are of contemporaneous origin.

In another locality, just west of the town of Napanee, a cliff on the southeast side of the valley of the Napanee river is scoured from base to summit, a height of about 125 feet, although upstream above and downstream below the scoured area the same cliff shows no well marked traces of glacial erosion. There is a slight turn in the direction of the cliff line at the locality in question, and it is this fact that probably led to the unusual amount of scouring at this place.

Again, on the north side of the American channel of the Saint Lawrence river, about a mile and a half below Carleton island, there are a number of places where, in passing down into the valley, the ice has cut deeply into the cliff crest of the ancient and now submerged valley side, producing deep grooves or channels. One of these, a type of them all, is about 25 feet across, about 5 feet deep at the lowest point of the curved or rounded bottom. The angles where the curve of the bottom intersects the striated flat surface of the adjacent parts of the cliff on either side is distinct and clear. The block that carved this channel was moved down into the valley parallel to the direction of the general movement of the ice in the locality, as shown by the numerous striæ on the flat surfaces elsewhere in the neighborhood. It entered the valley in a direction making an angle of about 45 degrees with its axial direction. 
In another locality on the second creek to the south of Chaumont creek, in New York state, glacial striæ on some meander spurs show that the ice which made the striæ moved across several meander curves deeply cut into the limestone without materially modifying their outline.

Some miles to the west of the particular area under discussion, along the front of the Niagara escarpment, there are found a few outlying areas, mesa-like, capped by Niagara limestone usually, that have not been carried away by the ice. One of these is known as the Milton outlier and is completely severed from the main escarpment by a deep ravine. Others of similar origin, with the valleys between them and the main cuesta partly submerged, form the islands in Georgian bay along the east coast of the Bruce peninsula. Other similar outlying areas are found in many localities in front of the Black River escarpment. Often it is found that in the rear of these outliers, when they lie some distance in front of the cuesta, there is a long train of loose angular blocks which have been dragged off the top of the outlier by the ice in its passage over the region.

In very many localities between Trenton and the line of the Niagara cuesta till sheets of several succeeding ice transgressions are found to override the till of the earlier glacial transgressions and the stratified gravels, sands, and clays of the several succeeding interglacial epochs. In a number of cases, the best known being that east of Toronto, at Scarboro, though several others occur farther east, it is known that there was a period of erosion, during which broad valleys were carved in the interglacial deposits which succeeded the lowest till sheets. The ice-sheet which deposited the sheets of till other than the lowest transgressed these valleys cut in the interglacial deposits, and in some cases partly filled them with till. In descending into them it seems to have created little or no disturbance of the underlying soft materials. In ascending on the opposite side it has crinkled and crumbled some of the strata where there were competent clay members to carry the thrust for some little distance back from the side of the valley in question In no case does it appear to have seriously modified the preexisting topography by extensive erosion of these soft deposits.

The relations of the various till-sheets and interglacial deposits between Trenton and Hamilton show that during the times of transgression of the ice, other than the first, it passed over very soft deposits, some of which lie within the valleys under discussion, without materially destroying by erosion the preexisting topography of these soft deposits. From this alone we might infer it would be highly improbable that the ice of the earlier period would have performed any more effective work on the bedrock topography. As has been shown, the bedrock features 
of the region are those characteristic of an area that has been exposed to stream erosion and normal weathering processes for a considerable interral of time, and subsequently have been slightly and locally modified by the ice transgression, in very small part by actual erosion, in large part by the deposition of loose debris.

As was noted above, in Prince Edward county there are large areas underlain by soft more or less decayed limestone rock with a very little sand intermingled. In places the depth of this material exceeds 4 feet. In very few places within the borders of the county are there areas with well developed striated surfaces. These surfaces are, however, occasionally found associated with the softer rock. In physical character and in composition these rocks are identical, both being Trenton limestone.

Inasmuch, then, as in certain areas it has happened that the rocks retain their striations, whereas elsewhere in the same district over large areas the rock in situ is very much decayed, the inference would be that the disintegration was largely pre-Glacial. That it may be so and that the soils which are still in situ have been left here by the ice-sheet is certainly also suggested by the apparent inability of the ice-sheet to significantly modify the rock topography by actual erosion anywhere on the limestone areas immediately north of lake Ontario.

In the vicinity of Kingston and southward in New York state it is found that fresh striated rock surfaces are much more abundant and cover larger areas than elsewhere. In these localities the old rock topography is still retained, nor is it materially modified. The fresher character of the striated surfaces is due in part to the slightly different character of the rock, and probably in large part to the proximity of the Adirondacks, from which a local glacier descended into what is now the basin of lake Ontario.

From the evidence as adduced above, it is inferred that all the essential features of the rock topography are of pre-Glacial date, and that the present valleys once formed part of what is now a dismembered river system.

\section{Trent River System}

\section{IN GENERAL}

All that part of the province of Ontario west of the Frontenac axis and between the bay of Quinte and the Archean areas on the north is drained by the 'Trent river or some of its tributaries. For purposes of description the Trent River system may be considered in two sectionsthe Central Ontario section, comprising all the streams and lakes whose waters enter the 'Trent river proper above the town of Trenton, and the Bay of Quinte section, comprising that portion of the Trent river which 
is at the same level as lake Ontario and to which most of the larger streams in this part of Ontario are tributary.

\section{CENTRAL ONTARTO SECTION}

What is usually considered as the headwaters of the main stream of the Trent system is a small lake near the main divide in central Haliburton county. From this lake a stream, the Gull river, makes its way southwesterly, alternately flowing in valleys between Archean ridges or expanding into small lakes in these valleys, and traversing the ridges in a more or less southeasterly direction, usually in a series of falls or rapids into the next adjacent valley eastward. Just to the east of Norland, where the river expands to form Mud Turtle lake, it enters the Black River cuesta. The islands and shores of Mud Turtle lake are usually of Archean rock, but a little distance back from the shore, on either side, is a limestone escarpment, which reaches its best development and is highest (125 feet) on the west. This escarpment, whose height above the river gradually diminishes as we proceed downstream, borders the river to below Coboconc at the head of Balsam lake. Here it is lost among drift deposits.

Balsam lake is a broad, shallow depression on the Black River cuesta. To the west the rock divide between it and lake Simcoe is but 5 feet above ordinary lake-level, while the surface of Balsam lake is about 60 feet above lake Simcoe. Whether the Balsam Lake depression is to be considered one of the partly blocked valleys of the pre-Glacial topography is doubtful. In certain features it seems to be composed of two of these, but at present this must be regarded as uncertain. About 4 miles south of Kinmount a small stream, Corben creek, enters it from the northeast. This creek comes from Four Mile lake, a lake occupying the head of one of the valleys of the first type described above, the upper end of the lake being located on Archean rock and the sides of the lake depression being limestone.

The waters of Balsam lake flow eastward in a shallow channel, cut chiefly in drift deposits, though one broad limestone ledge, a part of the typical flat-topped intervalley upland area, has been discovered by the river. The distance to the next lake on the main system, Cameron lake, is about 2 miles. Cameron lake is an oval body of water occupying a depression which is blocked to the south by drift deposits. The Burnt river, which rises on the Archean areas to the northwest, passes into the Black River cuesta through a deep reentrant about 6 miles to the northeast and enters Cameron lake at the same place as the discharge from Balsam lake. The Cameron Lake depression is really the lower part of the valley of the Burnt river, a valley of the first type here described. 
The discharge from Cameron lake, past the village of Fenelon falls, is through a new channel at the bottom of an older broad valley, with fresh cut canyon walls and a falls about 20 feet over bedrock into Sturgeon lake (plate 6). The distance between the lakes is a little over 2 miles. The depression in which the waters expand just below Fenelon falls marks a portion of one of the smaller valleys of the second type, tributary to the main valley, that occupied by Sturgeon lake proper. The Sturgeon Lake depression is the broadest and longest of the entire system. It lies wholly on limestone rock, Black river, at the northeast end, but chiefly Trenton. It is a valley of the second type, however, having no ancient opening toward the Archean. Northwest of the lake the basset edges of the limestone are found occasionally in the valley side. For the most part, however, near the depression at least, they are obscured by drift deposits. To the southeast the edges of the Trenton limestone may be found at the lake shore in a few places and in various places away from the lake. A low but well marked escarpment, with a cliff front in places, marks the southern edge of the valley and lies nearly 5 miles south of the lake. The extreme breadth of the valley is nearly 11 miles. The sides of the valley are usually evenly graded and covered with drift, and it is only in a few localities that the bed-rock outcrops. Following the depression toward the southwest both valley sides may be easily traced for over 36 miles from the discharge point of the lake. The southwest part of the valley is occupied by lake. Scugog, and the river Scugog, which enters Sturgeon lake below Lindsay, flows along the bottom of the valley. The depression continues about 4 miles southwest of lake Scugog, where it is obscured by the morainic deposits which form the main topographic divide of Central Ontario. In the vicinity of Scugog lake the valley in its present attitude is very broad and flat-bottomed, and the bed-rock is completely drift-covered. The nearest outcrop which the writer has seen is at Lindsay, about half way between lake Scugog and Sturgeon lake. Another outcrop is knowr. to occur some miles to the west of the lake and at a slightly higher level. The similarity of form between the valley sides of the Scugog depression and the Sturgeon Lake depression, where much bed-rock can be found, together with the perfect continuity of the two very strongly marked depressions, makes it highly probable that bed-rock lies not far below the surface anywhere in the vicinity of lake Scugog. The outlet stream from the northeast end of Sturgeon lake passes through a narrow young gorge cut in heavy-bedded Black River limestone to the depression occupied by Pigeon lake.

Pigeon lake is a slightly complex rock valley partly submerged. From the north there enters a small stream which rises on the Archean 


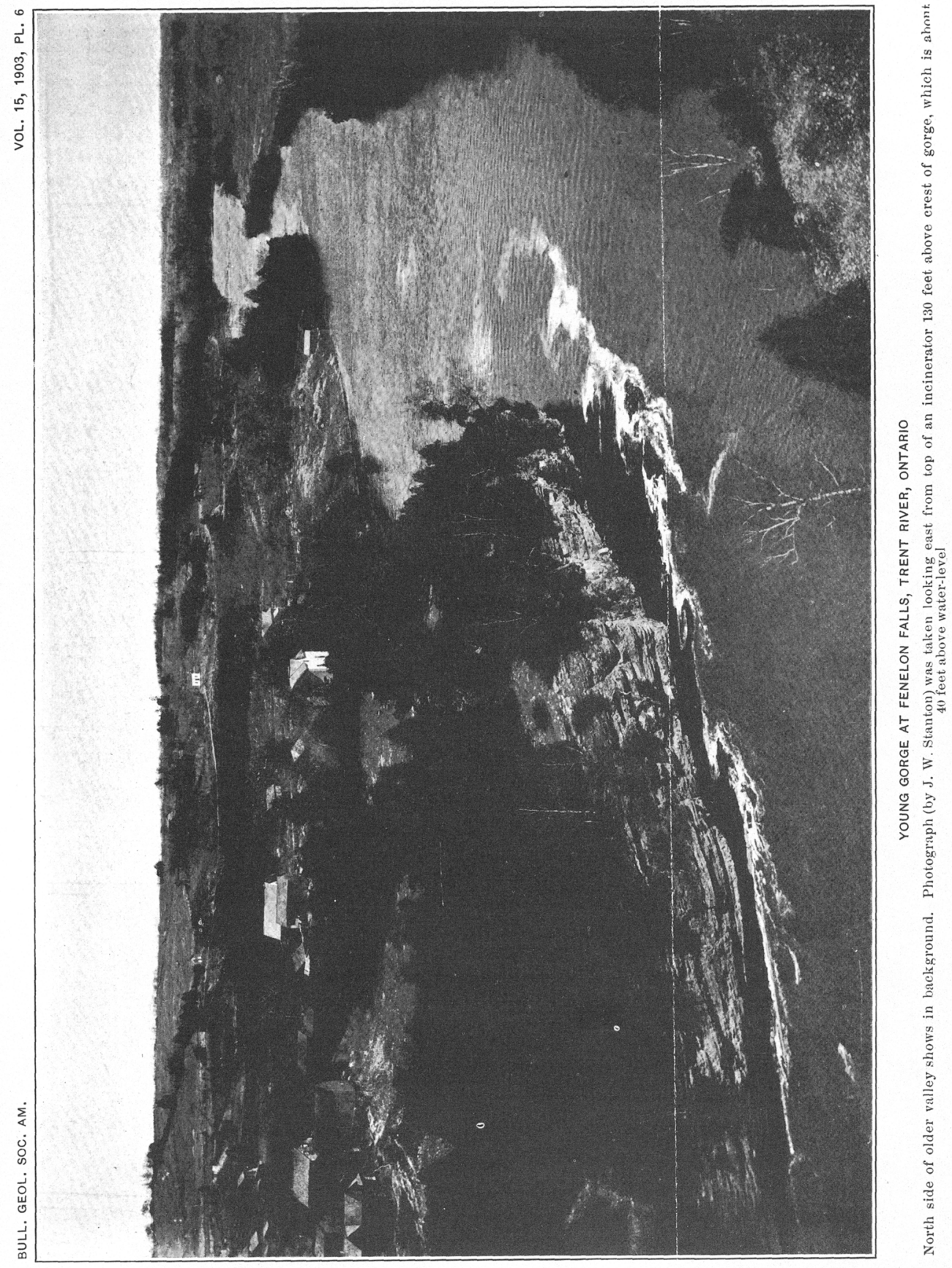


and passes through the Black River escarpment in a narrow valley. To the northeast there is another depression through which the waters of the lake reach the Archean. The western wall of the valley is sharply defined by a steep but not cliffed rock scarp; the eastern side is less well defined. To the south the water in the Pigeon Lake depression is joined to that in Buckhorn lake through a broad channel in which there is little or no current. The channel appears to be cut wholly in drift deposits. The Pigeon Lake depression for 5 miles below the outlet channel is flooded by the waters of the lake. Southwest of the foot of the lake it is still traceable to near Omemee, where it is obscured by heavy drift deposits. The stream which flows past Omemee into Pigeon lake and rises about 20 miles southwest of the foot of the lake may possibly mark the continuation of the depression near Omemee and to the southwest.

The principal depression whose flooded upper portion forms Buckhorn lake is also a rock valley of the first type. Sandy lake, which lies to the north of the west corner of the lake, also occupies a limestone valley, through part of which the outlet stream from Sandy lake flows. The main depression extends southwest from Halls bridge. It is well marked in its northeastern extent by bounding scarps. The southwestern part is less well defined. This part of the basin seems to be a shallow upland depression rather than one of the system of valleys in which southwest running streams once flowed. The general features suggest that it was drained by an obsequent stream which flowed to the inner lowland in the same direction as the waters now flow. The waters of Buckhorn lake connect directly with Chemung lake through a broad channel bordered by very flat low-lying land. To the northeast the discharge stream flows along the lowland in front of the cuesta. It continues in this direction as far as Stony lake, there being two small falls of a few feet each in its course.

About midway between Buckhorn lake and Stony lake the river expands into a water body known as Deer lake. The depression occupied by this lake is bordered on either side by steep nearly vertical cliffs with a heavy talus at the base-the sides of a partly submerged valley of the first type. At the lower (southwest) end this valley is partly obscured by drift; but the scarps can be traced to Chemung lake. About 2 miles below the foot of the lake a portion of the valley is occupied by a small lake known as Mud lake. The water from this lake flows in a small stream into Chemung lake, which occupies the lower portion of the same valley. The rock sides of Chemung lake, at the lower parts, are completely buried beneath the drift deposits. A well boring to the west of the lake near Ennismore showed the rock 
scarp to be about 150 feet above the lake, and below about 20 feet of drift. To the southeast of the lake between Bridgenorth ${ }_{1}$ and Peterboro there are heavy morainic accumulations in the form of drumlins, and no rock exposures are known to the writer until the valley of the Trent river, referred to below, is reached. The Deer Lake-Chemung depression continues to the southwest beyond the foot of Chemung lake for a considerable distance and its course is marked by a northwest flowing stream.

Stony lake, which lies on the Archean lowland in front of the cuesta, is the most picturesque of all the lakes of the system. The partly submerged roche moutonnée surface of the Archean has given rise to numerous small and rocky islands, for the most part covered with a limited growth of coniferous or deciduous trees. To the south of the lake the Black River cuesta, rising about 150 feet above it, forms a steep escarpment. About the middle of the south side of the lake the escarpment is broken through by the upper end of one of the valleys of the first type. The flooded upper portion of this valley forms Clear lake, on the same level as Stony lake. This valley with well marked rock scarps continues to near the village of Lakefield, Katchewanaka lake above Lakefield being but an expansion of the river in a broader, flatter portion of the valley. Near Lakefield the river is turned from the valley by drift deposits, and runs in a nearly straight course, in a channel which it has incised in the drift deposits and in part into the bed-rock underneath, to some distance below the city of Peterboro. The whole course from Lakefield to Peterboro, 9 miles, is marked by a succession of rapids. The river is here flowing over one of the typical intervalley upland areas. From Katchewanaka to Rice lake this section of the river is called the Otonabee river. The last noted exposure of limestone occurs in the river bed about 2 miles below Peterboro. From Peterboro to Rice lake, 21 miles by the river, the channel is cut in drift deposits and is graded. At 12 miles below the city it turns abruptly northeast and runs in this direction for about 5 miles, rounding the northeast end of a very large drumlin, when it again turns southwest and follows a straight course to Rice lake.

Rice lake is a long, narrew lake with a maximum depth of about 25 feet, a. length of 21 miles, and a maximum breadth of 3 miles. Along the whole length of its southeast shore extends a high ridge, in places rising about 600 feet above the lake. At the eastern end, near Hastings, and extending northeast from here to the next sharp turn in the river's course, the under part of this ridge is made of Trenton limestone. The greater portion of the ridge west of Hastings is buried under an immense morainic deposit of drift, which in places probably exceeds 300 feet in 
thickness. On the shore opposite the mouth of the Otonabee river the divide between Rice lake and lake Ontario lies less than 3 miles from the lake and about 11 miles from lake Ontario, being over 900 feet above the latter lake. On the north side of Rice lake, close to the lake, there are extensive drift deposits, and, so far as the writer is aware, no bedrock is known. A little farther to the north, however, east of Peterboro, bed-rock occurs at a higher level than the lake. This Rice lake valley extends for a considerable distance southwest of the head of the lake as a well marked depression. The general direction of the depression is shown by the course of the stream, which enters the soutbwest end of the lake at Bewdley.

Tributary to Rice lake from the north is the Keene river, whose general course is in accordance with the trend of the older valleys here described. Whether it actually occupies one of these is uncertain. Heading on the upland in the same region as the Keene-a flat, swampy district of glacial deposits, including sand and gravel plains-is the Indian river, which flows in almost exactly the opposite direction and enters Stony lake near its eastern end, cascading down the front of the Black River cuesta in a well marked obsequent valley.

From the foot of Rice lake the river extends northeast in the same valley, rock walled, steepest on the south, to a short distance below Trent bridge, where the depression is less well defined. Here it widens out a little and runs on top of the limestone for a short distance in an irregular course, finally turning southeast and flowing in a succession of rapids and falls through a new channel, the lower part being a gorge, until it empties into the next old valley to the eastward.

The upper portion of this valley is occupied by the Crow river. The Crow river in its upper course runs along the front of the cuesta as a subsequent stream, being the outlet for the waters from three lakesRound, Belmont. and Marmora-located on the inner lowland, besides a considerable amount of surplus drainage from the northeast. At Marmora it enters a well defined narrow rock-scarped valley, trending southwest, which gradually broadens. Below the junction with the Trent from the northwest this valley is well defined and rather broadly open as far as Campbellford. Below Campbellford the river leaves the old valley, which is blocked by drift, and flows in a new channel. For the first 2 miles below Campbellford it has not yet incised. the rock to any great extent. South of this as far as Meyersburg it runs in a shallow post-Glacial canyon, there being a heavy rapid and falls just below Campbellförd. Near Meyersburg it again turns east and widens out in a broad, shallow depression upon the limestone. This depression extends for a number of miles in either direction beyond the lowest 
portion occupied by the expanded river. It leaves this valley below Glencoe, turns again southwest, and flows as far as Trenton in a postGlacial canyon cut in the limestone. In this part of its course it has incised a valley through a heavy morainic ridge, and has cut a channel in the limestone to a depth of about 25 feet and of a width of nearly 300 yards. At Trenton the river enters the bay of Quinte at the level of lake Ontario.

It perhaps might be noted that the present location of new portions of the present Trent river (above Peterboro and above Trenton) and of the present Moira river (above Belleville) is probably intimately associated with the retreat of the last ice-sheet across Ontario. The problem has not yet been fully investigated, but certain field studies suggest that these streams, at the localities indicated, originally flowed along a valley between the morainic deposits to the west and the front of the retreating ice-sheet on the east.

\section{BA Y OF QUINTE SECTION}

In general.-A reference to the accompanying map (plate 7) will show that the bay of Quinte is naturally divisible into three distinct sections. A closer examination in the field shows that the first of these sections, that between Trenton and Desoronto, though rock-bound on both sides throughout its length, is really a complex of several valleys. The other two natural divisions-the Long reach and the Twelve Mile reach are less complex.

Trenton-Desoronto division.-The Trenton-Desoronto section naturally falls into two subdivisions--that between Trenton and Belleville (or Rossmore on the Prince Edward side) and that between Belleville and the Telegraph narrows just west of Desoronto. The first of these sections is one (possibly two) of these rock valleys with lightly scarped sides (rising 50 feet above water-level). It does not seem to be associated with the valley occupied by any modern stream (plate 7 , section I). Toward the west it is drift-blocked. West of the west end of the bay of Quinte, on the other side of a low limestone divide, is another valley, also unconnected with any modern stream. Parts of the rock ridge which bound this depression on the south are exposed at Presqu' Isle, where they form a scarp facing the north and rising 35 feet above present water-level. The rocky ridge which forms Presqu' Isle is joined to the mainland by a long sand neck formed across the outlet of this valley by the waves of lake Ontario.

The only tributary of importance which enters the western section of the bay of Quinte is the Moira. As already noted, this flows as a subsequent stream in front of the Black River cuesta for nearly 15 miles, 


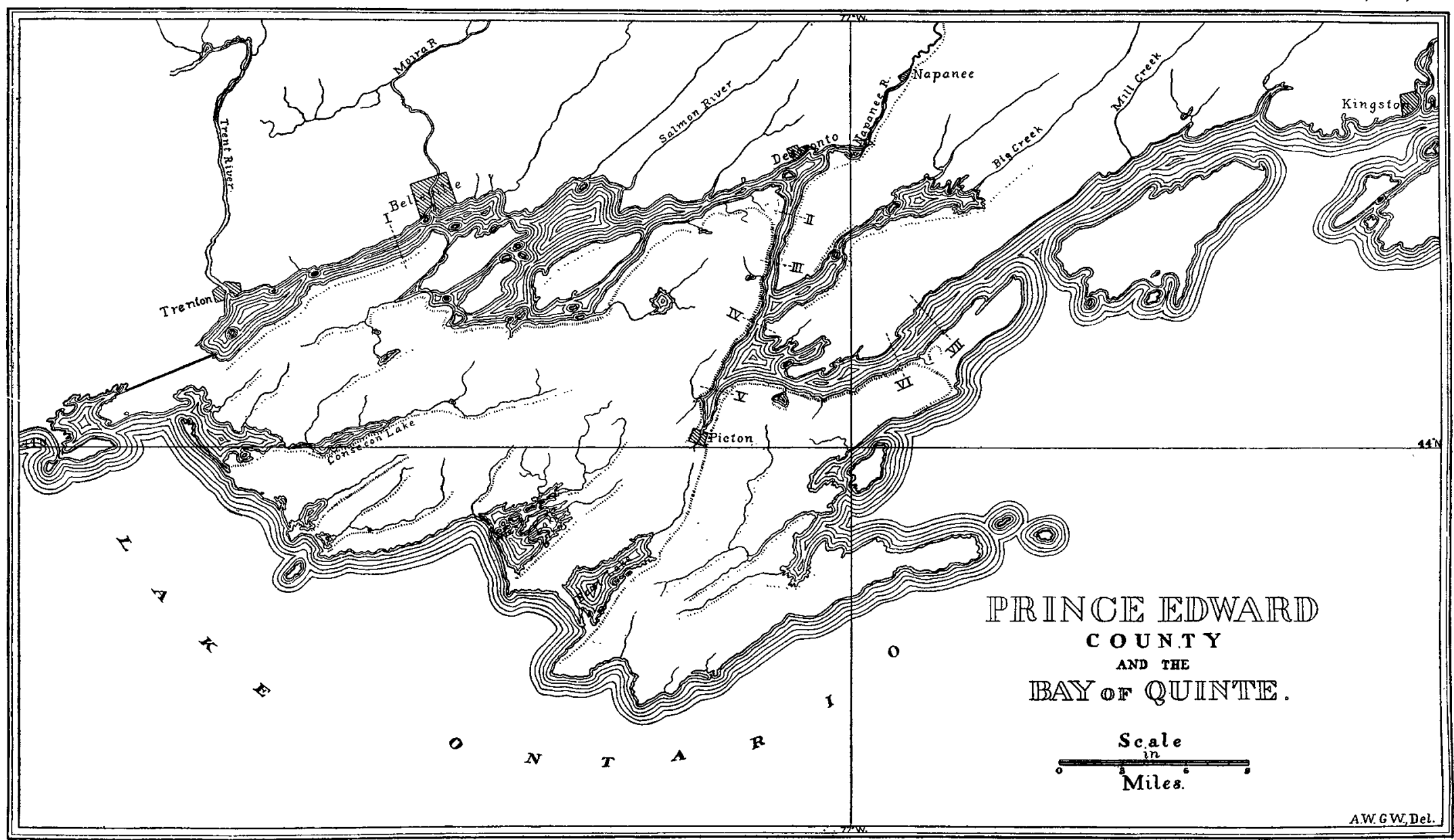

Figure 1.-Prinoe EDward County and Bay of Quinte

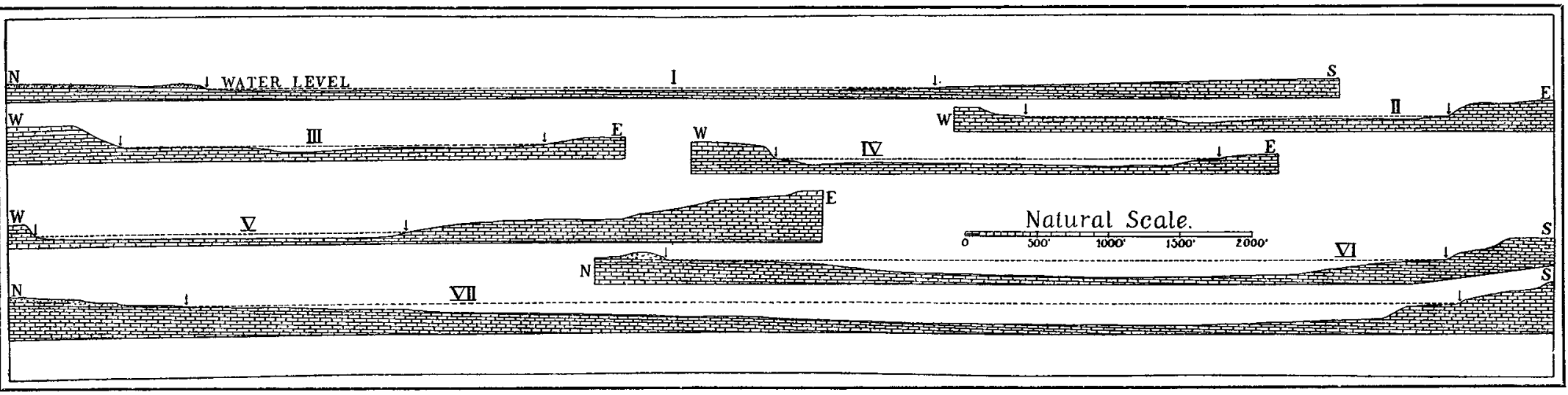

Figuhe 2.-Profile Sectiong across the Bay of Quinte

MAP AND SECTIONS OF PRINCE EDWARD COUNTY AND BAY OF QUINTE 
Moira lake, just south of Madoc village being an expansion of the river on the inner lowland. It enters the cuesta below Stoco lake (also on the inner lowland) in a valley of the first type, follows this valley for about 8 miles, until displaced by morainic deposits near Thomasburg, whence it flows in a new channel cut in drift until it is joined by an important tributary from the northeast near Plainfield. This tributary in part of its course, and in all probability in all of it, occupies one of the old rock valleys. The united streams continue in the course of the old valley to Foxboro, where they turn south and flow with numerons rapids through a new channel in a straight consequent course to the bay of Quinte at Belleville.

The eastern portion of the Trenton-Desoronto division is more complex, and it is necessary first to refer to the most important tributary stream, the Salmon river. This stream enters the limestone escarpment from Beaver lake, the latter lying on the inner lowland near Tamworth. The valley of the Salmon all the way across the limestone area is deep and, relatively to the valleys of the other streams, narrow and very steep scarped, especially on the southeast side.

Running along the south shore of the bay from Green point opposite Desoronto to Northport, and thence southwest past Demorestville and Crofton and across Prince Edward county to the north of Consecon creek and lake, is a well defined cuesta. At Telegraph narrows, about 4 miles west of Desoronto, the bay is very shallow, and rock is exposed in numerous places on either side and forms islands in the bay. Telegraph narrows probably marks a local divide between waters which flowed in front of the cuesta eastward to join the valley of what is now the Napanee river and the Long reach, and westward in front of the cuesta along the general course now indicated by the direction of its crest. This valley was confluent with that of the Salmon river to the west of what is now Big island. This main valley was probably joined in the vicinity of what is now Wellers bay, on the west coast of Prince Edward county, by the stream which carved the valley now occupied by Consecon creek and lake. Several other minor valleys are also associated with the Salmon river valley, but in the absence of topographic maps it has not been possible to work out all the details as yet. The unsubmerged portions of the intervalley areas of these confluent valleys form the three large islands southeast of Rossmore.

Long reach and Napanee river.-The Napanee river rises on the Archean upland to the northeast of the Black River cuesta, and traverses the limestone region in a deeply incised valley, the rock scarps of which may be followed all the way across from the front of the cuesta to the bay of Quinte. The scarps on both sides along the upper portions of the valley, 
where it is narrow, are sharply defined and often precipitous. As it gradually broadens, that on the north side becomes less steep, the cliff features nearly disappear, so that in the vicinity of Desoronto it has an even slope to its summit. The scarp on the east side, retaining its steep cliff-like character, is continuous with the high scarps along the eastern side of the upper portion of the Long reach. From the vicinity of Desoronto the course of the old valley seems to have been toward the south, in a direction more nearly in accordance with the dip of the strata. As a result, we find the sides of this portion of the valley bounded by steep rock cliffs, that on the west, the highest, rising about 185 feet above the bottom of this section of the bay (plate 7 , sections II-V). The scarp on the west side is the edge of the cuesta, on whose outer slope several of the minor streams of Prince Edward county take their rise. It runs from the vicinity of Green point, where it is continuous with the scarp before noted as lying to the south of the upper part of the bay of Quinte, to Picton, and thence southwest across the county, gradually losing its cliff character west of Picton and becoming an evenly graded slope.

Confluent with this consequent valley is another less broad, rockscarped valley, the submerged portion of which now forms Hay bay. Hay Bay valley can be traced all the way across to the inner lowland, and Big creek drains a small area of the lowland through the escarpment to the bay.

To the south of the Twelve Mile reach is a high escarpment, rising near Glenora to 225 feet above bay-level and 308 feet aboveits bottom. This escarpment forms the east side of Picton bay and extends across Prince Edward county, with gradually decreasing elevation, to the south of East lake, being submerged beneath the waters of lake Ontario at Salmon point (plate 7, sections VI and VII). This escarpment is the south wall of a broad valley which joined the ancient Napanee valley from the east a few miles above Picton. The united streams crossed Prince Edward to East lake. The lower portion of this valley is now traversed by a sand bar thrown up by the waves of lake Ontario, and the submerged portion of the valley behind this bar forms East lake.

The south side of the Twelve Mile reach east of Glenora, where it reaches its maximum height, gradually diminishes in elevation above present lake-level. The depth of the water in the bay gradually increases, however, to a maximum of 230 feet half way between the west end of Amherst island and the main shore, so that the actual depth of the valley is fairly uniform. With one interruption, where a portion is submerged and past which it can very readily be traced by means of the soundings, the escarpment continues to the east end of Amherst island. Between Prince Edward county and Amherst island the channel which breaches 
the valley wall is 2 miles in width and has a maximum depth of 83 feet, the depth of the water in the valley being 230 feet. At present it has not been possible to determine satisfactorily whether this main valley, whose submerged portion forms the Twelve Mile reach, is to be considered as the southwest extension of the valley through which Collins creek traverses the limestone areas. The valley of Collins creek is one of the rock valleys of the first type running through the limestone region from the inner lowland. The lower submerged portion forms Collins bay. This valley and the Twelve Mile Reach valley are directly in line, and this suggests that they may be parts of the same ancient valley. On the other hand, the charts show the existence of a depression of considerable depth (106 feet below water-level) between the Brother islands and the main shore, suggesting that Collins creek may have here turned eastward to join the valley which forms the next section of the bay-a case of pre-Glacial stream capture. Another alternative is that the valley of the next section of the bay and the Twelve Mile Reach valley were continuous. On the other hand, the maximum depth of the submerged divide across the Lower gap ( $4 \frac{1}{2}$ miles wide) between Amherst island and Simcoe island is only 6 feet higher than the greatest depth in the adjacent part of the bay, the latter being 106 feet below present waterlevel. So far as known, the bottom in this locality is all rock, with but a very small amount of drift. As will be seen by a reference to the map, the Lower gap is a continuation of the Bateau channel east of Kingston (described below), and from the general field relations it seems best to interpret it as the lower, and hence wider, portion of this valley rather than to consider it as a breach in the side of a valley which might have been continuous from East lake to below Kingston.

Kingston section.-The next section of the bay heads on the Archean areas east of Kingston, and runs southwest as a narrow valley, with steep rock scarps on either side at its eastern end. Between Howe island and the mainland, where it is narrowest and the rock sides are steep, it is known as the Bateau channel. The valley walls rise to a considerable height, over 100 feet, above present water-level. The south side is interrupted in one place by a cross-channel between Howe island and Wolfe island. So far as the present soundings are concerned, the present line of deepest water turns through this channel from the upper portion of the bay. The general field relations, on the other hand, are very strongly in favor of considering that the portion of the bay north of Wolfe island is a direct continuation of the Bateau channel.

Tributary to the bay, Cataroqui creek enters from the north. It crosses the limestone area in a deep broad valley, carving a typical "shut-in" 
canyon in an Archean spur which crossed its path, and joins the bay near Kingston.

The north shore of the bay west of Kingston as far as the Long reach is throughout its course a gently graded rock slope, in marked contrast to the cliff front of the cuesta on the south side. Several minor streams, all in rock valleys of the second type, enter the bay between the long reach and Collins bay.

Saint Lawrence section.-The Americall outlet channel of the Saint Lawrence river is also one of these submerged valleys. The south shore in its present attitude is bordered by a more or less graded scarp. Near Clayton a small stream flowing in a valley of the second type enters it from the southwest. The head of the valley is located in the narrow channel between the Archean ridge which forms Wells island and the main shore to the south. The north side of the American channel is less abrupt than the south. Along the eastern portion of Long island it is bordered by a low cliff scarp. From the crest of this scarp the rock rises inland with a gentle graded slope to an elevation of probably 50 feet above water-level, with somewhat higher points in several places.

The cross-channel between Howe island and the mainland to the east, joining the Bateau channel with the main river, is connected with a series of Archean valleys north of Grindstone and Wells islands. The north shore of the same channel north of Grindstone island is also Archean rock. The south shore of Howe island is obviously a partly submerged rock bluff, such as borders all the valleys. The north shore of Long island opposite is also bed-rock. It is quite probable that the channel between the two islands marks the valley of a stream confluent with that which carved the Bateau channel, and that the rather broadly open valley from the west end of Howe island to the Lower gap was the work of the two streams.

FAULT THEORY OF ORIGIN OF BAY OF QUINTE DEPRESSION

The very remarkable zigzag course that is taken by Trent river in its upper part, and the no less remarkable course of the bay of Quinte, would naturally suggest that these topographic features were due to extensive faulting, and that the escarpments were the edges of uplifted blocks. The writer made a careful search for indications of fault movement in the field, but was unable to find evidences of any such movement. On the contrary, it was found in every case, without exception, that the differences between the opposite sides of any of the complex of valleys was invariably such as could readily be explained by the relative attitudes of the plane of slope of the valley and the plane of dip of the 
rocks, and that there are but little differences in height between the opposite sides. This relation holds systematically throughout the whole region. Again, where the Napanee river enters the Black River cuesta (this is also true of all the others crossing the cuesta) the escarpments on either side are of equal height, and, so far as could be determined, of precisely the same rock (actual identification of individual beds made elsewhere was not attempted here). The escarpment on the southeast is perfectly continuous to the vicinity of the inlet of Hay bay, where it gradually lowers to water-level. Throughout its course it retains nearly the same character, the rocks dipping away from the cuesta front. The opposite side of the valley gradually assumes a more graded slope, and although the basset edges of the strata are exposed, the general slope is very much gentler in the vicinity of the bay of Quinte than it is farther inland. On the opposite side of the bay the corresponding part of the cuesta (west of the Long reach) exhibits features identical with the portion of the cuesta to the east of the Long reach. The slight difference in height between the western and eastern sides of the Long reach is apparently associated with the character and dip of the rocks.

The block-fault theory to account for the origin of the zigzag course of these valleys is regarded by the writer as at present untenable, because there is no known evidence in its support, and it is not necessary to assume it to explain the relations of the various valleys and escarpments. The limestone rocks throughout the whole region are extensively jointed. In a very few'cases there has been a slight local movement along the joint planes. In no instance has the writer noted a displacement of over 6 inches in a vertical direction. The direction of the master joint fractures is intimately associated with the trend of all the master valleys, though the modern post-Glacial channels are independent of them. It is quite probable that they, to a large extent, controlled the direction of the drainage of the area subsequent to the peneplanation of the limestones. It is not improbable that much of the drainage was at first subterranean along the line of the master fractures. Indeed, in one instance (Perch creek) the present stream flows along a joint fracture underground for a distance of nearly a mile. 'I he intimate relation between the jointing and the valley sides is well shown in the cliff front along the west side of the Long reach, where, when considered in detail, it is found that systematically the slight salients and reentrants of the cliff are the obtuse intersections of joint fissures. The distances between these local salients are remarkably uniform alongt he whole 9 miles of cliff, producing a scrolled appearance. 'These master joints with their associated valleys and the parallel systems of valleys of similar trend 
on the adjacent Archean areas are probably associated with an extensive system of faults of pre-Orodovician date.*

\section{Notes on other Streams Tributary to Lakke Ontario from the East}

In all essential features the valleys of the southwest-flowing streams in New York state are similar to those in Ontario. To the south and west of Clayton, and southeast as far as Black river, there are large relatively flat areas, the intervalley uplands, with a very limited drift cover and frequent exposures of flat limestone rock. A number of small creeks head on the different parts of this upland and flow southwest, the valleys gradually becoming well defined as they grow wider and deeper. The partly submerged western portions of these valleys form the numerous inlets on the eastern shore of lake Ontario. Without a single exception, the islands off that coast are merely partly unsubmerged portions of the rock wall between two valleys. The valley of Three-mile creek extends for some distancc above the head of the present stream, and is well defined by a low rock scarp on either side, the valley lying below the level of the upland plain. 'The writer did not have the opportunity of ascertaining whether it extended completely across the limestone area.

The Chaumont river occupies a valley of the first type of those described above, although the present river does not come from the inner lowland. 'The head of the present stream lies in a flat limestone plain between bounding rock scarps. A couple of miles farther east another stream heads in the same valley and flows northeast. The lower portion of the valley is submerged to form Chaumont bay. A reference to the map (plate 8) would suggest that the former courses of the valley of Threemile creek and Chaumont river were between point Peninsula and the mainland. In the field, however, it is found that it is extremely improbable that this was so, because rock exposures are found close together at or near water-level, even on the neck between the peninsula and the mainland. The earlier course of one of the streams may have been across this neck, because there is a well defined valley here, but the course of the pre-Glacial Chaumont river seems to have been to the south of the point Peninsula. Three Mile creek at one time probably flowed between the peninsula and the mainland, but at a later stage it appears to have joined the Chaumont river, possibly a case of local stream capture, the bottom of the valley of the creek, now submerged as Threemile bay, being at a considerably lower level than the bottom of the sag in the rock surface at the neck of the Peninsula. The valleys of the smaller streams marked by Guffin bay were tributary to Chaumont

* This also has beeu suggested to the writer by Doctor Gilbert. It is proposed to discuss the problem in a later paper on the origin of roches montonne. 


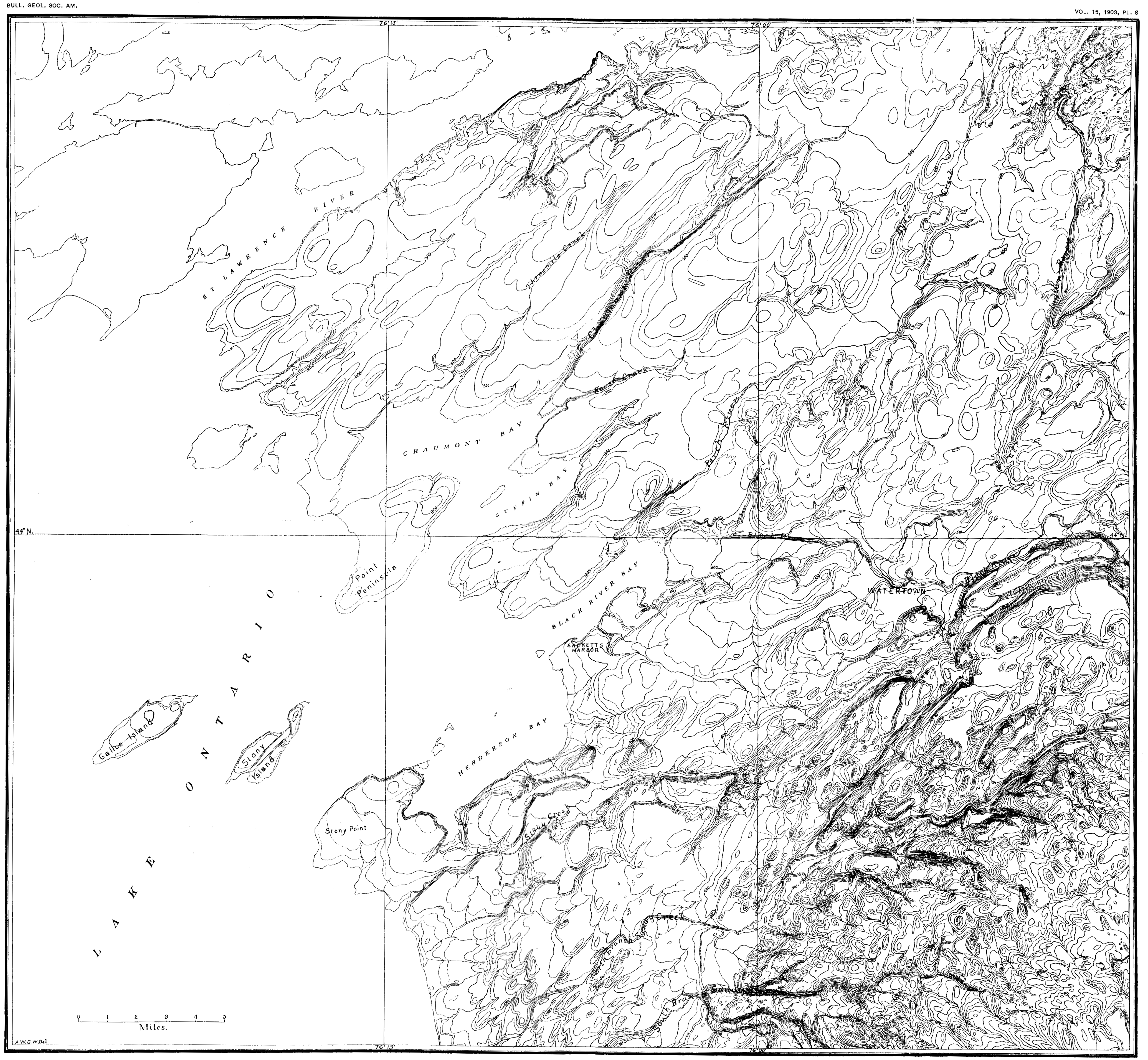




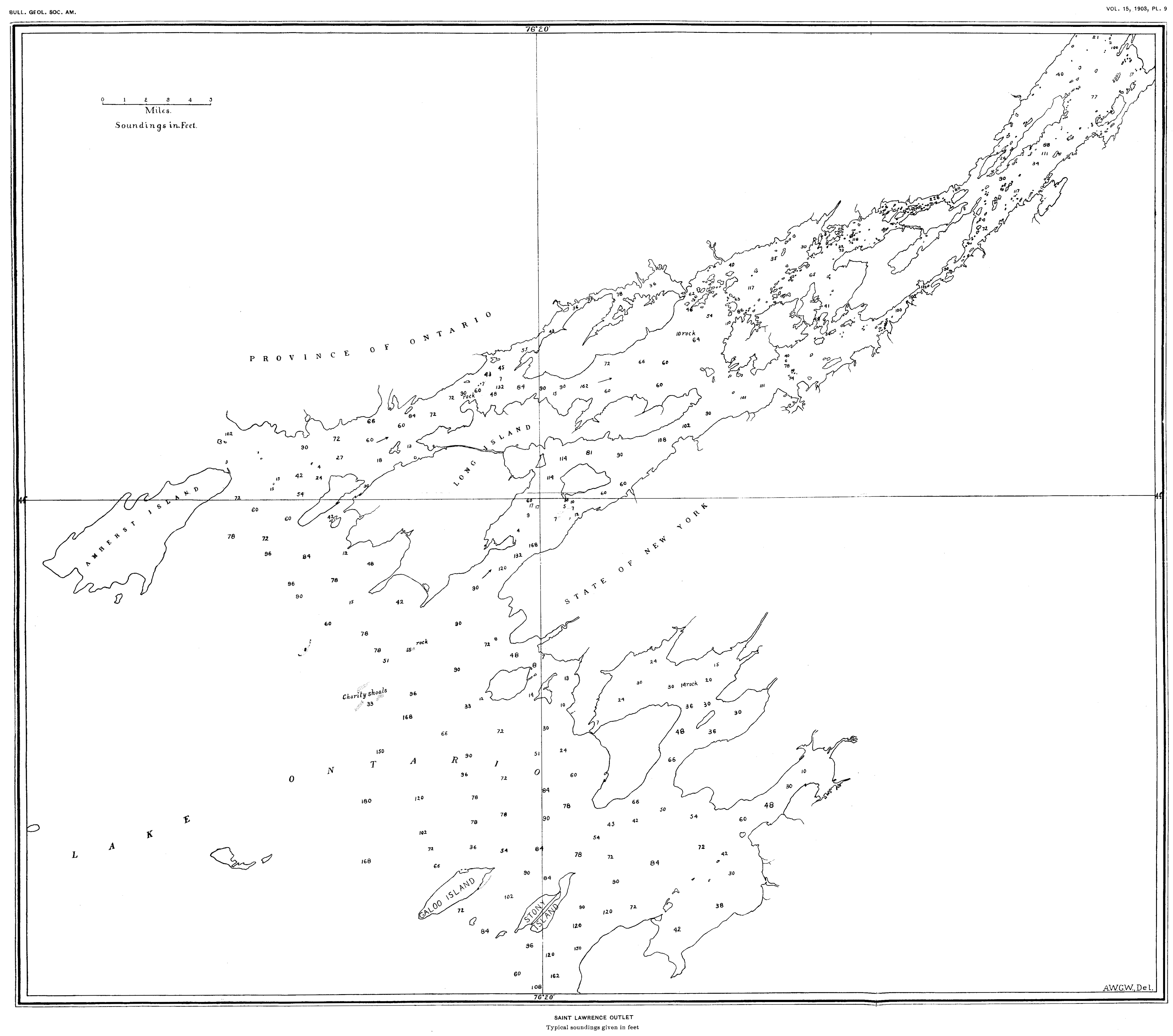


valley. From the soundings in this part of the lake, it is inferred that the ancient Chaumont valley was tributary to the ancient Black River valley which lies to the south of Stony island.

The next stream to the south is Perch creek. This stream rises near the Archean areas to the northwest of Theresa at Hyde lake. Under the local name of Hyde creek it flows across the Potsdam lowland in a well defined rock-scarped valley to Perch lake. This latter lake is located in a reentrant in the limestone cuesta. From Perch lake it flows southwest through the cuesta to Black River bay. About a mile below the village of Limerick, the present stream passes underground and follows a subterranean channel for nearly a mile. The older valley on top of the limestone is well defined, and judging from the bare character of the valley floor and the distribution of debris, at times of flood the present stream occasionally flows overground. At Limerick the present channel is a slightly sinuous rock gorge, about 50 feet in width and 20 in depth. In places the sides are locally rounded, though most of the gorge is cliffed. The general features of the gorge sides are such as to suggest that it is pre Glacial, and that its form has been slightly modified by the ice. It is quite possible that the portion near Limerick is of glacial origin, owing to the down fracturing of the roof of the subterranean channel under the weight of superincumbent ice.

The largest and most important of the streams which cross the limestone areas to enter the eastern end of lake Ontario is Black river. The larger part of the catchment basin of this stream lies in the Adirondacks. The main stream flows along the inner lowland in front of the Paleozoic cuesta for many miles above Carthage, receiving a few short obsequent tributaries which run down the cuesta front. About 7 miles north of Carthage it turns abruptly and flows southwest toward Watertown. At Watertown the course changes a little to the north of west* and follows this direction to Black River bay. This bay is merely a partly submerged portion of the river valley. The course of the valley can readily be followed by the soundings to the southwest of Stony point, lying between the point and Stony island. The modern stream in its course across the limestone areas has cut out a rocky gorge in the bottom of the older flat-bottomed valley, and this gorge forms the present channel of the river. At Black river the gorge has a depth of about 40 feet. To the south of the old valley the walls are steep and often cliffed. To the east of Watertown and about a mile and a half from Black river is a very remarkable steep-sided rock valley called Rutland hollow, cut as it were on the side of the old Black River valley, since the upland to

\footnotetext{
*A pre-Glacial modification not yet fully investigated, but evidently closely associated with the joint structure.
} 
the south rises 313 feet above its bottom, and the bottom is 225 feet above Black river. This valley passes out toward the lowland to the northeast. Its southwest extension is occupied by Mill creek, and at one time the creek which occupied the Rutland hollow probably flowed outward in this direction. At a later stage in its history the headward growth of a small lateral affluent of Black river has intercepted the headwaters of the old stream by breaching the valley side. At the present time the drainage of the hollow is carried to Black river by this side stream, entering the river about a mile and a half east of Watertown.

Just west of Watertown another small stream enters Black river from the northeast. Following up the valley of this we find that it is continuous with the valley of West creek, a northeast-flowing stream. The course of the valley is little obscured by drift, but the cliffed rock scarps a little higher on the west are to be seen near Evans mills. West creek enters Indian river just at the big bend, a mile northeast of Evans mills. The nose of the sharp spur around which Indian river bends is an Archean ridge. The amount of Archean rock now actually exposed is small, and the greater part of the point is underlain by a flat arenaceous limestone, marked as Potsdam on the geological map of New York state. The valley of Indian river, both above and below the bend, is deeply incised and has a broad flat bottom, the basset edges of the incised beds showing on the sides of the valley. A short distance above the bend and also a short distance below it (about a mile and a half), it has cut down to the Archean rocks. There is a strong probability that at one time there were here two streams, each flowing in a southwest direction along the edge between the sediments and the Archean rocks and confluent at what is now the bend. From this point the course of the confluent stream was southwest along the valley of West creek and thence to Black river.

South of Black river, Muskalonge creek, Mill creek, and several other streams flow in rock valleys more blocked by drift than are those north of Black river, but showing in general features all the characteristics of the unobstructed valleys to the north.

\section{The Saint Lawrence Outhet}

The water from lake Ontario passes into the Saint Lawrence by two main channels. One is through the Lower gap, near Kingston, and thence eastward, either to the north or to the south of Howe island. The other is between Wolfe island and the south shore. A section across the river near the west end of Howe island will cross three channels separated from one another by large limestone islands. Following each of these eastward to its lower end, if one considers the direction of water 
movement, upper end if one considers the form of the channel valley, it is found that the valley gradually becomes narrower and shallower. The most northern, the Bateau channel, at its east end turns abruptly to the south to join the middle channel. Following the middle channel eastward, it is again found to narrow and become shallow rapidly ; to reach the main river it again turns to the right of its axial direction. The third or American channel narrows and shallows eastward as do the others. Between Wells island and the mainland its course is somewhat sinuous.

The western ends of each of the channels are submerged rock valleys of the first type here described. The islands between the channels mark unsubmerged portions of the valley sides. Each of these valleys and the ridges between them may be traced southwest for a considerable distance under the waters of lake Ontario (plate 9). The upper ends of each of the channels are located on the Archean belt. Each channel ends in a well defined valley between Archean ridges, partly submerged, it is true, but the ridges stand above water-level as the largest islands of the Thousand Island group. A study of the topographic features of the Thousand Island group shows that it is the characteristic semi-submerged Laurentian topography that is found in literally hundreds of other places throughout the Iaurentian peneplain. We find the same succession of longitudinal valleys between ridges of Archean rocks, the axes of the ridges being parallel to the strike of the rocks, and the same series of shallower connecting straits across sags in the ridges. A reference to the map will show that an almost exactly similar system of longitudinal and cross-channels would be formed were the regions to the north of the present river submerged.

That each of the valleys with limestone sides become narrower eastward is due in part to the shape of the valley and in part to the fact that the highest point of the partly submerged Frontenac axis lies to the east of the eastern ends of the valleys.

From the foregoing descriptions and by reference to the accompanying maps, it will be seen that the outlet course of the Saint Lawrence river is not a well defined channel, but rather is a complicated series of channels. In fact, it is a series of partly submerged longitudinal basins, with crossconnections between the basins, the complex forming what is erroneously termed the channel of the Saint Lawrence. In reality the river has no channel of its own west of the Frontenac axis. East of the axis, in the lower parts of its course, it has cut a modern channel in drift deposits. The immaturity of parts of the channel east of the axis is shown also by the braided character of the stream. It is probable that east of the axis the course of the river is in part also of a compound character. 
The investigations as to the history of this portion of the stream are not yet sufficiently advanced to warrant extended discussion at this time.

\section{Summary and Conclusions}

In writing the foregoing description of the topography of the country bordering the east end of lake Ontario, it has been necessary to omit reference to many interesting minor details. In the majority of cases only those features which seem to bear directly on the question of the origin of the Saint Lawrence outlet, and on the problem of the origin of the principal features of the region, have been described and discussed. It remains but to summarize the results of the foregoing study.

In the first place, the balance of evidence with regard to the amount of erosion by the ice-sheets which transgressed this region is distinctly in favor of the conclusion that this erosion was very slight. The main points on which this conclusion is based are:

1. The unquestioned fact that the ice-sheets which succeeded the earliest sheet whose till rests on the bed-rock overrode soft stratified and unstratified deposits which were the work directly or indirectly of the earlier ice-sheets, without materially altering the preexisting form, in so far as the evidence of the numerous cross-sections shows what that form may have been; from this it is inferred that there is little likelihood of the first sheet having been a more effective erosive agent.

2. The topographic features are similar to those produced by stream erosion in unglaciated regions, and bear no definite relation to the direction of the ice movement. On the contrary, their systematic development quite independently of that movement, accurate adjustments even to small details, and retention of characteristic forms show that the amount of erosion by the ice was very limited. They antedate the period of ice-transgression, at whose close the earliest till sheet was deposited, and by which the striations on the bed-rock beneath that till sheet were produced, as is evidenced by the occurrence of both the till and the striations in the valleys as well as on the uplands.

That the complicated system of valleys here described is due to stream erosion is inferred, as already stated, from their similarity in form and adjustments to valleys produced by stream erosion elsewhere in unglaciated regions. The direction of flow of the streams which carved them is inferred to have been southwest because uniformly throughout the system the valleys are found to become wider, frequently deeper, and always more mature in form as one proceeds from their heads on or near the inner lowland outward toward the region to which they now drain.

The main stream of the Trent River system is seen to alternately flow in a new channel of post-Glacial origin and in a course along an ancient 



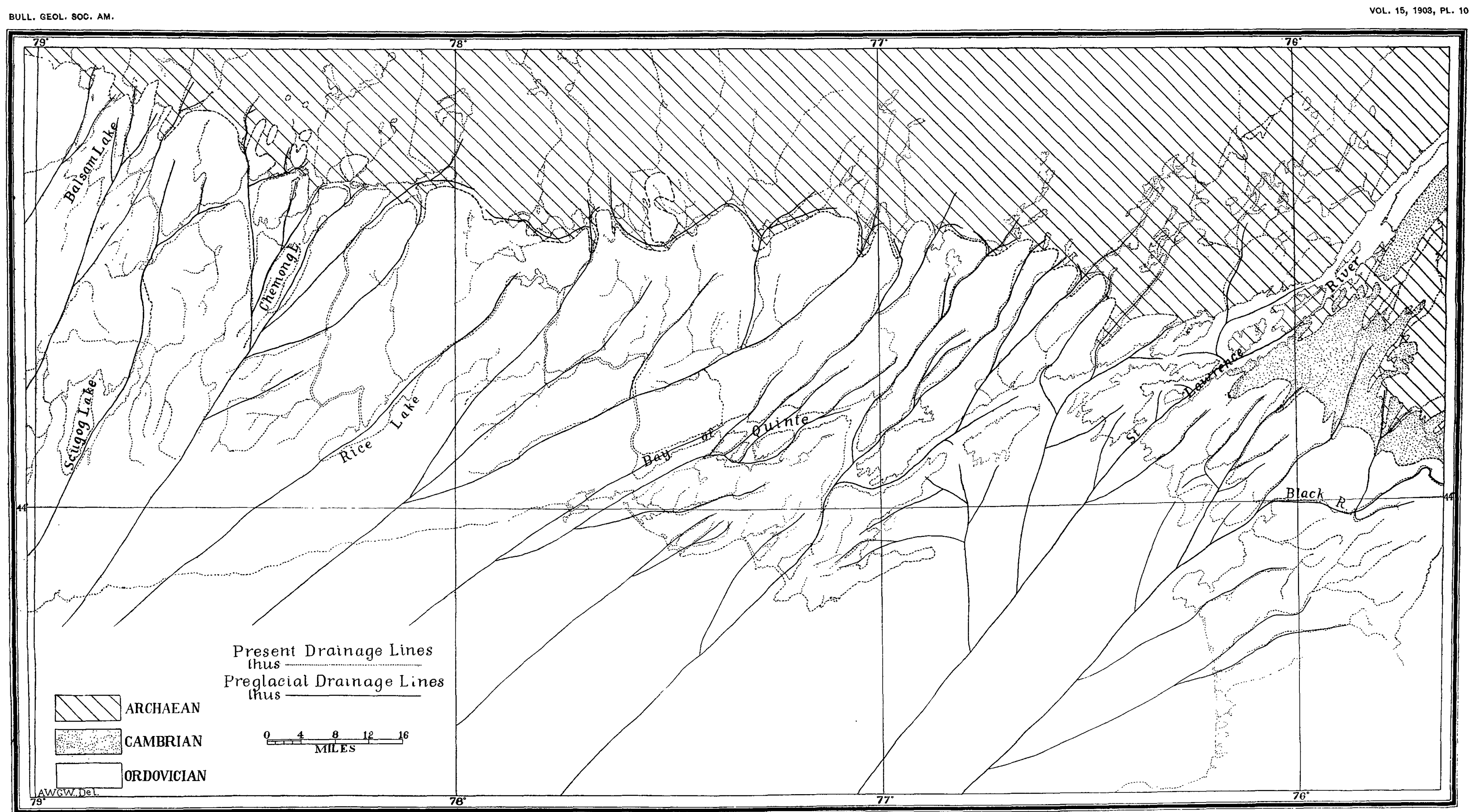

PREgLACIAL DRAINAGE OF AREA AROUND NORTHEAST END OF LAKE ONTARIO 
pre Glacial valley. The new channel almost always follows a direction consequent on the present attitude of the upland surface. This is strikingly shown in the long section of rapids between Lakefield and Peterboro (9 miles), in the section of rapids below Campbellford ( 5 miles), and in the section above Trenton (7 miles). A similar feature is shown by the Moira between Foxboro and Belleville.

In its course from the divide in central Haliburton to the bay of Quinte, the Trent passes through parts of 9 of these pre-Glacial valleys, and there are several others indirectly associated with it (plate 10). It should also be mentioned that there are several more of these valleys developed to the west of the Trent system, whose descriptions have been omitted from the present discussion. In every case there is sufficient rock exposed along the valley sides to show that their upper parts are carved in the rock. In many cases rock exposures are found along both sides of the valley throughout its length. In some cases, as in the Scugog valley, and in that of the western part of Rice lake, the existence of bed-rock directly associated with all parts of the valley is unproven; it is found associated with the northeast end of each valley, however. But even here the nature of the slopes of the valley sides and the fact that they are uniformly continuous with the part where the rock does occur make it extremely probable that it is not far below the surface, even where the existence of rock sides has not yet been proved. Again, it would be extremely improbable that without the existence of some such predisposing cause, the drift deposits would always happen to have been deposited in such a systematic position with reference to the rocksided upper portion of the valley as to always extend it in an appropriate direction and with accordant grades.

The southwest extensions of all these valleys, north and west of Trenton, are blocked by the heavy morainic deposits of Central Ontario. The result is that in their present attitude their lowest parts form the basins of an extensive chain of small lakes. The new channels of the Trent river mark merely the lowest edges of the rims of each of these basins, the river spilling over this rim to the next adjacent valley at a little lower level.

The portion of the Trent system at lake-level, the bay of Quinte, is seen to consist of a complex of at least 7 of these ancient valleys, partly submerged, so that the details of the adjustments and interrelations between the various members can not always be satisfactorily determined. The unsubmerged parts of the bay of Quinte system of valleys are all occupied by streams tributary to the bay. In Prince Edward county a similar system of rock-sided valleys has been developed with minor north-facing cuestas, only in part associated with the Trent system.

In New York also it is found that valleys similar in every respect to 
those north of the lake have been developed on the bed-rock, and these still preserve all the essential features of valleys produced by river erosion.

The so-called outlet channel of the Saint Lawrence river is in reality a complex of three partly submerged valleys similar to the bay of Quinte. The portion of the Saint Lawrence in the vicinity of the Thousand islands is merely a series of longitudinal basins with connecting straits across sags in the interbasin ridges. No definite channel exists. The topography is similar to that characteristic of partly submerged Laurentian areas found in many places over the great Laurentian peneplain.

The courses of the rock valleys associated with the Saint Lawrence outlet and of the rock valleys of New York to the south of the river may be traced for a considerable distance on the bed of lake Ontario by means of the soundings.

The water of the Saint Lawrence system passes eastward at the present time over the lowest part of the Frontenac axis. The existence of the sag over which the river passes is probably due to local differential depression. The direction of flow of the water west of the submerged divide on the axis is opposite to that in which the water flowed when the valleys were carved in the limestone area. East of the divide on the axis the direction of Hlow is probably as it was in pre-Glacial times.

At a time prior to the existence of lake Ontario the valleys forming the Saint Lawrence outlet, all the valleys of that part of New York east of lake Ontario, the valleys of the Bay of Quinte section of the Trent system, and the valleys of Prince Edward county formed part of a river system now dismembered.

Finally, it may be suggested that the maturity of form, the size, and the course toward the deepest part of lake Ontario suggest that the pre-Glacial Black river was the master stream of the system. Its course and position with reference to the Niagara cuesta suggest that it was a master subsequent stream flowing in front of the cuesta westward. Probably some of the streams in the valleys forming the lakes on the upper part of the Trent system were tributary to this master subsequent stream either directly or in a few cases after confluence with each other.

As has been pointed out by Grabau* and the writer $\dagger$ independently, this master subsequent was probably joined. by a second master subsequent from the north, flowing south in front of the Niagara cuesta, the two subsequents being confluent in the vicinity of the depression whose submerged portion forms Burlington bay, at Hamilton, Ontario; thence they probably followed the course of an initial consequent stream through the Niagara cuesta via the Dundas valley to the Erie lowland.

*A. W. Grabau : Guide to the Geology and Paleontology of Niagara Falls and Vicinity. N. Y. State Museum Bulletin, xlv, 1901.

†Physical Geology of Central Ontario. Trans. Can. Inst., vol, vii, 1901, p. 181. 